\title{
Örgütlerde Yaşanan Sessizlik Olgusunun Kişisel Özellikler Bağlamında Araştırılması: Nitel Bir Çalışma
}

\section{Zeki UÇAR ${ }^{1}$}

\begin{abstract}
$\ddot{O} z$
Bu araştırmada, işgörenlerin açık bir şekilde konuşup konuşmama kararı vermelerine etki ettiği düşünülen bir takım kişisel (psikolojik ve demografi temelli) özelliklerin ortaya çıkarılması ve bu özelliklerin işgörenlerin sessizlik davranışını ne şekilde etkilediğinin nitel bir araştırmayla ortaya konması amaçlanmıştır. Kalitatif bir araştırma olarak tasarlanmış çalışmada veri elde etmek için mülakat ve odak grup tekniklerinden yararlanılmıştır. Araştırma örneklemi farklı örgüt yapıları içerisinde değişik kademelerde görev alan kırk bir katılımcıdan oluşmaktadır. Araştırma sonucunda kişilerin daha çok yaşamla mücadele tarzlarını ortaya koyan "kontrol odağl”", "benlik saygısı" gibi kişisel özelliklerinin yanında cinsiyet, ĕgitim gibi bazı demografik özelliklerin bireylerin sessiz kalıp kalmama yönünde vermiş oldukları kararları etkilediği anlaşılmaktadır.
\end{abstract}

Anahtar Kelimeler: Örgütsel Sessizlik, İşgören Sessizliği, Kişisel Özellikler, Demografik Özellikler

JEL Sinıflandirma Kodlart: L2, L20, L31

The Analysis of The Phenomenon of Silence in Organizational Investigated in the Context of Personal Characteristics: A Qualitative Study

\begin{abstract}
In this study, it is aimed to reveal personal characteristics of employees (depending on psychological and demographic) that affect their openly speech and these characteristics in what way effect the silence behavior of employees. In the study was designed as a qualitative research, data were obtained semi structured interviews and focus group techniques. The research sample is consists of fourtyone participants have assignmen at different levels in different organizational structure. The result of research show that in addition to personal characteristics reveal struggle for life style of individuals like "locus of control", "self-esteem" some demographic characteristics of the individuals like gender, education effect their decisions they have given direction to remain silent.
\end{abstract}

Keywords: Organizational Silence, Employee Silence, Individual Characteristics, Demographic Characteristics

JEL Classification Codes: L2, L20, L31

${ }^{1}$ Araş. Gör. Dr., Bitlis Eren Üniversitesi İktisadi ve İdari Bilimler Fakültesi, İşletme Bölümü, zeki.ucr@gmail.com 


\section{Z. UÇAR}

\section{GİRIŞ}

Son dönemlerde, özellikle de örgüt çalışmaları üzerinde yoğunlaşan işgören sessizliği araştırmaları, örgütsel alanda ortaya koymuş olduğu sonuçları itibariyle sorunun ne denli önemli olduğunu açıcça ortaya koymaktadır. Nitekim sessizlik olgusunu örgütsel alan içerisinde ele alan bir çok araştırma, örgütler açısından yaşamsal olan bu konunun öneminin yöneticiler tarafından kavrandığını ortaya koymaktadır (Quinn ve Spreitzer, 1997, Vokola ve Bouradas, 2005: 441; Shojaie vd., 2011: 1731). Nitekim, yöneticilerin, küresel rekabetin yüksek düzeydeki dinamizmiyle yarışabilmek ve küresel rekabeti yönetebilmek için çalışanlarından risk alma, açık konuşma ve sorumluluk almaları yönünde çok daha fazla talepkâr davrandıkları görülmektedir. (Shojaie vd., 2011: 1731). Çünkü örgütlerin çevreleri giderek daha karmaşık, daha dinamik hale gelirken (Gao vd., 2011: 787); değişim gösteren bu durumlarla birlikte farklı zorluklarda kendini hissettirmektedir. Örneğin, küresel rekabetin yoğun baskısı altında sürekli değişim gösteren müşteri beklentilerini karşılamak örgütler açısından oldukça zorlaşmaktadır. Yöneticilerin farklı bakış açılarından uzak, kendi başlarına bu zorlukları belirlemeleri, yorumlamaları ve onlarla başa çıkmaları mümkün gözükmemektedir. Bu noktadan hareketle işgörenlerin, organizasyonu ilgilendiren ve/veya ileride karşılaşılması muhtemel kritik öneme sahip sorun ve konulara ilişkin düşünsel kapasitelerini ortaya koyup farklı eleştiriler, çözümler ve yeni fikirler üretmeye çalışmaları yönetimsel kademelere destek yönünden, örgütler için hem değerli (Premeaux ve Bedeian, 2003: 1537) hem de ekonomik bir kaynaktır.

Örgüt ortamında oluşan durumlara bire bir tanıklık eden, gerekli bilgilere rahatça erişebilecek pozisyonlarda bulunan ve çeşitli uzmanlıklara sahip olan işgörenler, örgüt içinde gerçekte neler olduğuna dair farkındalık yaratan en önemli bilgi kaynaklarıdır. $\mathrm{Bu}$ bağlamda işgörenlerin ilgili yerleri bilgilendirmeleri organizasyonların davranışlarına rehberlik noktasında oldukça önemli bir etkiye sahiptir (Clapham ve Cooper, 2005: 707). Örgütler adına önemli olan, işgörenlerin sahip oldukları organizasyonla ilgili bilginin yukarı yönlü akışını sağlayabilmektir. Ancak organizasyonları geliştirebilecek fikir, bilgi ve düşüncelere sahip olan 
işgörenler, bazen sahip oldukları bu fikir, bilgi ve düşüncelerini dile getirebilmek ve ilgili yerlere iletebilmek için çaba gösterirken bazen de bunun tam tersi bir duruş sergileyerek bir sessizlik hali içine girmektedirler (Van Dyne vd., 2003: 1359). Bu durumda işgörenlerin sessizleşmelerine neden olan faktörlerin ortaya çıkarılıp hiyerarşik basamaklar arasında bilgi akışını sağlamak, örgütler adına hayati derecede bir sorun olarak organizasyonların karşısında durmaktadır.

Ancak "sessizlik" gibi içinde davranışsal bir takım ipuçlarının bulunmadığı ve bu yönüyle belirgin davranışlardan ayrışan bir olgunun araştırılması ve farklı örüntülerinin betimlenmeye çalışılması, çeşitli zorlukları içermektedir. Nitekim Johannesen (1974) konuşma eylemi olmadığında sessizlik davranışının var olup olmadığının kesin olarak anlaşılmayacağını ve bu duruma dikkat gösterilemeyeceğini belirtmektedir (aktaran Van Dyne vd., 2003: 1364). Ayrıca, Danışman ve Özgen (2003) bilinçaltı düzeyde yer alan temel varsayımların anlaş1lıp değerlendirilebilmesi için, büyük ölçüde, etkileşime dayalı mülakat, katılım, gözlem ve etnografik çalışmalar gibi niteliksel yöntemlerin gerekli olduğunu belirtmektedirler. Tüm bu nedenlere bağlı olarak kişinin psikolojik alanı dışındaki ikinci şahıslar tarafından somut olarak eyleme yansıyıp yansımadı̆̆ 1 anlaşılmayan sessizlik davranışının, keşifsel yöntemler kullanılarak derinlemesine araştırılması gerekmektedir. Çünkü sessizlik gibi araştırılması zor olan bir olgunun, nicel yöntemlerle yüzeysel olarak araştırılması çeşitli kısıtlara neden olacaktır. Örneğin örgütsel alanda sessizlik olgusuna ilişkin örüntülerin ne şekilde geliştiği anlaşılamamaktadır. Dolayısıyla bu araştırma kuramsal destekten yoksun olarak ilişkilendirilen kişisel özellikler ve sessizlik olgusuna kuramsal destek sağlaması açısından önemlidir.

Aykanat (2012: 20) yapmış olduğu çalışmada bir olgunun ne şekilde geliştiği ve ne anlam ifade ettiğini ortaya çıkarmanın "anlama”; anlama sonucunda elde edilen bulguların, diğer disiplinlerde var olan bilgilerin yardımıyla açıklanmasının da "anlamlama" olduğunu belirtmektedir. Sessizlik olgusunun kendi bütünlüğü içerisinde sadece davranışsal çıktılara odaklanmayıp, aynı zamanda olgu üzerinde "anlama ve anlamlama" ya yönelik çalışmalarının yapılması, sessizlik olgunun ne 


\section{Z. UÇAR}

şekilde ortaya çıktığını ortaya koyarken diğer taraftan bu durumu önleyici yönde daha etkili yönetim uygulamaları ve insan kaynakları stratejileri geliştirilmesine olanak sağlayacaktır. Belirtilen nedenlere bağlı olarak bu çalışmanın amacı aşağıdaki gibi özetlenebilir:

1- İşgörenlerin kişisel özellikleri düzleminde işgören sessizliğinin nedenlerini keşfetmek ve bu ilişkiyi betimlemek,

2- Elde edilen bulguları, örgüt ve yönetim yazını kapsamında açıklayan kavram ve olguların, örgütsel alanda yaşanan sessizlikle olan ilişkilerini tartışmak.

\section{LITERATÜR ARAŞTIRMASI}

Son dönemlerde örgütlere zarar veren bir olgu olarak kavramsallaştırılan örgütsel/işgören sessizlik olgusu, farklı birçok yönüyle akademik araştırmalara konu olurken; çeşitli disiplinlerden beslendiği (psikoloji, sosyoloji, antropoloji vb.) görülmektedir. İşgörenlerce bilginin amaçlı ve bilinçli olarak gerekli ve/veya ilgili yerlere aktarılmaması olarak ele alınan İsgören Sessizliği/Örgütsel Sessizlik (Employee Silence/Organizational Silence), organizasyonlarda oldukça yaygın görünen bir durumdur (Pinder ve Harlos, 2001; Morrison ve Miliken, 2000). Ancak organizasyonlarda bu denli yaygın görülmesine karşın, işgören sessizliği kavramı örgütsel davranış ve yönetim yazınlarında ancak son yıllarda araştırmalara sıklıkla konu olmaya başlamıştır (Tangirala ve Ramanujam, 2008: 38; Morrison ve Milliken, 2000; Pinder ve Harlos, 2001 ).

Kavramın kökenine inen araştırmaların temel olarak Hirschman'ın (1970) çalışmasına atıfta bulundukları anlaşılmaktadır. Aslında Hircshman (1970) her ne kadarda sessizlik kavramını doğrudan çalışmış olmasa da kavramı dolaylı olarak ortaya koymaktadır. Hirschman (1970) tarafından kullanılan sessizlik kavramının, pasif ancak, yazarın aynı çalışmasında üçüncü bir değişken olarak kullanmış olduğu bağlılıkla (loyalty) eş anlamlı olarak kullanıldığı görülmektedir. Hirchsman (1970) tarafından işgörenlerin pasif bir durumu olarak ele alınan bağlılık kavramı, işgörenlerin yapıcı bir tutum olarak sessizleşip itaatkâr davranmalarını ima 
etmektedir. Denilebilir ki, Hirschman bağlılığı tanımlarken aslında sessizliği de tanımlamaktadır. Bu nedenledir ki örgütlerde yaşanan işgören sessizliği ile ilgili çalışmaların neredeyse tamamına yakını referans noktası olarak Hirschman'ın (1970) çalışmasını kaynak göstermektedir.

Hirschman (1970) "sesliliği” örgütsel tatminsizliğe karşı bir yanıt olarak ele almış olan ilk sosyal bilimci olarak, bu durumu performansta yaşanan bir düşüşü takiben müşterilerin ya da örgüt üyelerinin (Hirschman, 1970: 30) nasıl davrandığını betimleyen bir tipoloji önererek ortaya koymaktadır (Brinsfield vd., 2009: 8). Hirschman (1970) müşterilerin ya da örgüt üyelerinin tatminsizlik durumunda iki farklı davranış şekliyle yanıt verebileceklerini öne sürmektedir. Bunlar "Çıkış” (Exit) ve "Ses” (Voice) dir (Brinsfield vd., 2009: 8). Hirschman'ın (1970: 4,30) çalışmasında "çıkış" bazı müşterilerin organizasyonun çıktılarını satın almaktan vazgeçmeleri ya da bazı örgüt üyelerinin örgütten ayrılmaları şeklinde tanımlanırken, "ses" ise müşterilerin ya da örgüt üyelerinin firmanın uygulamalarını, politikalarını ve çıtılarını değiştirme teşebbüsü olarak tanımlanmaktadır. Hirschman'ın (1970) yapmış olduğu bu tanımdan hareketle "çıkış”, organizasyon üyelerinin örgütten ayrılarak tüm bağlarını koparmaları anlamına gelirken; "ses” ise şikâyette bulunmak, çeşitli önerileri dile getirmek, örgütle ilgili bazı problemleri yöneticilerle tartışmak gibi çeşitli formlarda ortaya çıkabilmektedir (Afşar, 2013: 5).

Hirschman'ın (1970) ele almış olduğu üç boyuta ek olarak Rusbuld, Zembrodt ve Gunn (1982) ve Farrell (1983) tatminsizliğe tepki olarak dördüncü bir boyut ortaya koymaktadır. Bu dördüncü boyut umursamazlık, aldırmazlık ve sessizlik ile karakterize edilen "ihmal” kavramıdır. Farrell (1983) çalışmasında, deneyimlemiş oldukları tatminsizlik sonucunda organizasyona karşı bağl11ıkları azalan ve yapmış olduğu işe yabancılaşan işgörenin, organizasyon içerisinde katılımdan uzak durup umursamaz davranışlar sergileyeceğini öne sürmektedir (aktaran Brinsfield vd., 2009: 9-10) . Ayrica Farrell (1983), sesi aktif ve yapıcı bir boyut olarak ele alırken, ihmalin pasif ve yıkıcı bir durum olduğunu değerlendirmektedir (aktaran Brinsfield vd., 2009: 9-10). Bu noktadan hareketle Brinsfield vd. (2009: 10), 


\section{Z. UÇAR}

Hirschman (1970) ve Farrell'in (1983) çalışmalarında "ses" e yönelik olarak zıt bir tutumun olduğu dikkat çekmektedirler. Hirschman tarafından yapıcı bir durum olarak sadakat ve bağlılıkla eş olarak görülen işgörenlerin sessizlik halinin, Farrell (1983) tarafından yıkıcı bir durum olarak ortaya konması, özellikle 2000'li yılların başından itibaren yoğunlaşan sessizlik çalışmalarıyla tam bir paralellik gösterirken (örn. Morrison ve Milliken, 2000; Pinder ve Harlos, Dyne vd., 2003; Premeaux ve Bedian, 2003; Tangirala ve Ramanujam, 2008; Brinsfield vd., 2009), sessizliğin pasif bir durum olarak değerlendirilmesi ise kısmi bir paralellik sergilemektedir (örn. Dyne vd., 2003).

Farel (1983)' in çalışmasından sonra, Hirschman (1970)'ın çalışmasına ağır bir eleştiri de Leck ve Saunders (1989: 220) tarafından getirilmektedir. Leck ve Saunders (1989: 220), Hirschman'ın (1970) çalışmasına ilişkin bazı temel sorunlara dikkat çekmektedirler. Yazarlara göre Hirscman'ın (1970) çalışmasının tartışmalı yönlerinden en önemli olanı, araştırmada ele almış olduğu bağlılık (loyalty) kavramı yorumlanmasında ortaya çıkan karmaşıklıktır. Araştırmacılar bu duruma kanıt olarak Hirschman'ın (1970) “bağlılık” kavramıyla gerçekten kastetmek istediği şey üzerine yapılan tartışmaların iki farklı yöne evrilmesini göstermektedirler. İlk bakış açısında Hirschman (1970) bağ l1lığı, çıkış-ses kararının bir düzenleyicisi olarak tanımlamaktadır. Bu bakış açısına göre yüksek düzeyde bağl1lık gösteren tatminsiz çalışanlar çok az ihtimalle "çıkış" seçeneğini, çok yüksek ihtimalle de "ses" seçeneğini kullanacaklardır. Düşük düzeyde bağl1lık gösteren çalışanlar ise bu durumun tam aksi ile ifade edilmektedir. Aslında bağl1lığın bu şekilde kullanımı, bağlılı̆̆ın tatminsizliğe karşı gelişen davranışsal yanıtlarını etkileyen tutumsal bir durum olarak yorumlanmasına imkân sağlamaktadır. Diğer taraftan Hirschman (1970: 38) bağl1lığı ses ve çıkış seçeneğine bir alternatif olarak tanımlamış ve bağl11ık gösteren bir çalışanın çıkış seçeneğine karşı direndiği, sessizleşerek acı çektiğini ve inançlı bir şekilde bir şeylerin ileride düzeleceği kanısına sahip olduğunu dile getirmektedir. $\mathrm{Bu}$ bakış açısına göre de bağl1lık, durumun düzelmesi için sabır ve sükûnet içinde bekleme halidir. Çıkış ise ses kararını düzenleyen bir tutumsal durum olmaktan ziyade, 
bağlılığın tatminsizliğe davranışsal bir yanıtı olarak yorumlanabileceğini önermektedir (Leck ve Saunders, 1989: 220).

Doksanların ortasından başlayarak özellikle 2000'li yılların başlarında insan davranışlarını inceleyen bilim adamları sessizliğin eylemsizliği ifade ettiğini (Nader, 2001: 162), diğer bir ifade ile sessizliğin geleneksel anlamda pasif bir davranış olduğunu eleştirmekte (Scott, 1993: 3) ve hatta bazı yazarlar bütün sessizlik türlerinin pasif bir davranış olarak değerlendirilmemesi gerektiği, aslında sessizliğin biliş, duygu ya da niyetleri içeren iletişimin bir formu olarak, aktif ve bilinçli bir çabanın sonucunda oluşabileceğini belirtmektedirler (Pinder ve Harlos, 2001: 333-334). Dolayısıyla sessizlik kavramı üzerine yapılan değerlendirmelerde bir paradigma değişimi görülmektedir. Başka bir anlatımla, sessizlik araştırmalarının sonuçları itibariyle ilk çıktığı zamanlardaki olumlu davranış paradigmasının yerini genel olarak işgörenlerin bilinçli/amaçlı olarak sergiledikleri olumsuz bir davranış paradigmasına bıraktığı söylenebilir (örn. Morison ve Milliken, 2000; Pinder ve Harlos, 2001; Van Dyne vd., 2003; Morison ve Milliken, 2003; Premeaux ve Bedian, 2003; Bowen ve Blockman, 2003; Tangirala ve Ramanujam, 2008). Bu çerçevede sessizlik literatüründeki paradigma değişiminin etkileri örgütler üzerinde de kendini göstermektedir. Morrison ve Milliken (2000) yapmış oldukları çalışmada örgütlerde yaşanan sessizlik olgusunu, katılımeı bir örgüt yaratma önünde büyük engel olarak değerlendirmektedirler. Diğer taraftan, bu olgunun örgütün özelliklerinden etkilendiği de ifade edilmektedir (Morrison ve Milliken, 2000; Vakola ve Boudaras, 2005; Bowen ve Blockman, 2003; Bell vd., 2011). Bununla birlikte, günümüzde sessizlik olgusu, işgören performansını ve dolayısıyla da örgüt performansını olumsuz yönde etkileyen bir davranış biçimi olarak da kavramsallaştırılmaktadır (Çakıcı, 2007: 149).

$\mathrm{Bu}$ paradigma dönüşümü ve örgütlerde sessizlik olgusunu araştıran temel araştırmalar olarak Morrison ve Milliken (2000) ve Pinder ve Harlos (2001) tarafından yapılan çalışmalarla birlikte yönetim ve örgüt yazınında iyiden iyiye kendini hissettirdiği ve sonrasında örgütsel sessizliğe ilişkin birçok çalışmanın ardı ardına geldiği görülmektedir. 


\section{Z. UÇAR}

Yönetim ve örgüt yazınında "Örgütsel Sessizlik" kavramının ilk olarak Morrison ve Milliken (2000: 709) tarafindan kullanıldığı görülürken, benzer bir kavramı Pinder ve Harlos (2001) "İşgören Sessizliği” olarak tanımlamaktadırlar. İşgörenlerin örgüt içerisinde ortaya çıkan problemler hakkında kendi fikir ve endişelerini açık bir şekilde ifade etmekten kaçınmaları ve algılamış oldukları tehlikelerden kendilerini korumaları olarak literatüre konu olan ve ilk olarak Morrison ve Milliken tarafından (2000) kavramsallaştırılan "Örgütsel sessizlik" olgusu, örgüt düzeyinde ele alınan ve örgüt içerisinde yayılan ve örgütte bir iklim halini alan durumu yansıtmaktadır. Buna karşın Pinder ve Harlos (2001) kavramı birey düzeyinde ele almakta ve çalışmalarında bu durumun nedenlerini ortaya koymaya çalışmaktadır.

Morrison ve Milliken (2000) tarafindan "örgütsel sessizlik" olarak kavramsallaştırılan olgu, genellikle işgörenlerin örgütsel konu, problemler hakkındaki kendi fikir seçim ve endişelerini açık bir şekilde konuşmaktan bilinçli olarak kendilerini alıkoymaları, engellenmeleri olarak tanımlanırken (Vokola ve Bouradas, 2005: 441); çoğulcu örgüt yapısının önündeki en büyük engel olarak değerlendirilmektedir. Yine aynı yazarların Academy of Management Review'da yayınlanan "Sounds of Silence" (sessizliğin sesi) adlı çalışmasında örgütsel sessizlik, mevcut uygulamaların beklenilen şekilde etki göstermediğini ortaya koyan olumsuz geri bildirim ya da bilgilerin engellenmesi suretiyle etkili bir organizasyonel öğrenme ve gelişmeden taviz vermek, şeklinde tanımlanmaktadır (Morrison ve Milliken, 2003). Morrison ve Milliken (2000) çalışmasında olumlu bir örgütsel özellik olarak tanımladıkları çoğulcu örgüt tanımından hareketle örgütsel sessizliğin örgütler için neden zararlı olduğunu tartışmaktadırlar. Yazarlara göre çoğulcu örgütler, çalışanlar arasındaki değer ve hareket tarzlarının farklı olduğu ve işgörenlerin çoklu bakış açıları ve farklı fikirlerini ifade etmelerine izin veren örgütler olarak tanımlanmaktadır. Morrison ve Milliken (2000: 707) bu tanımdan hareketle örgütlerde çoğulcu sessizliğe vurgu yaptığını belirttikleri örgütsel sessizlik olgusunu, çoğulcu (katılımcı) örgütlerin gelişmesinin önünde bir 
engel, örgütlerin değişimi ve gelişimi önünde potansiyel bir tehlike olarak değerlendirmektedirler.

Yönetim ve örgüt yazınında Morrison ve Milliken'in (2000) çalışmalarıyla birlikte en fazla atıf alan çalışmalardan bir diğeri de 2001 yılında Pinder ve Harlos tarafından gerçekleştirilen çalışmadır. Yazarlar ilk kez "İşgören Sessizliğii" kavramını literatüre katmış ve işgörenlerin hangi nedenlerden kaynaklı olarak sessiz kaldıklarını keşifsel bir çalışmayla ortaya koymaya çalışmıştır. Pinder ve Harlos (2001: 334) tarafindan "işgören sessizliği”, örgütsel durumlar hakkında işgörenlerin bilişsel ve/veya etkili değerlendirmelerini içeren gerçek ifadelerini, etkili çözüm ve değişiklik kapasitesine sahip olarak değerlendirdikleri kişilerden esirgemeleri olarak tanımlanmaktadır.

Morrison ve Milliken (2000) ve Pinder ve Harlos (2001) çalışmalarının devamında, Dyne vd.'nin (2003) işgören sessizlik davranışlarını ortaya koymak ve bu davranış biçimlerinin örgüt düzeyine genellemek amaciyla ölçek geliştirme çabası içerisine girdikleri görülmektedir. Bu amaçla araştırmacıların, ilk olarak iletişim, etik ve sosyal psikoloji ve yönetim yazınlarına ilişkin var olan araştırmaları betimsel bir bakış açısıyla inceledikleri görülmektedir. Bu incelemeler sonucunda işgörenleri sessizleşmeye iten temel güdüleyicileri ortaya koymaktadırlar. Araştırma bulgularında işgörenlerin sessiz kalmalarının temelinde korku, özgecilik ve işbirliği yapma güdülerinden hareketle proaktif sessizlik davranışı ve rıza gösterme ve boyun eğmeye dayalı olarak da pasif sessizlik davranışı gösterdikleri ortaya konmuştur.

Dyne vd.'nin (2003) spesifik bir sessizlik tanımı yapmadıkları anlaşılmaktadır. Ancak Dyne vd., (2003) var olan çalışmalardan hareketle ses ve sessizlikle ilgili olarak yeni bir kavramsal çerçeve sunduklarını iddia etmektedirler. Bu kavramsal çerçeve içerisinde ilk olarak ses ve sessizliğin bilinçli (purposeful/amaçlı) formlarına spesifik olarak odaklanılmış ve iş ile ilişkili gelişmeler hakkında işgörenin fikir, bilgi ve düşünceleri ifade etmek yerine kendisini bundan alıkoyması ya da engellemesine neden olan güdüler (motive ediciler) üzerine yoğunlaşmışlardır. Yazarlar her ne kadar bu çalışmalarında işgörenlerin ses ve 


\section{Z. UÇAR}

sessizlik konusunda karar verirken bilinçli ve kasıtlı olarak hareket ettikleri üzerine odaklansalar da organizasyon içerisinde gerçekleşen tüm sessizlik durumlarının bilinçli ya da kasıtlı bir durumu yansıtmayacağı vurgusunu yapmaktadırlar. $\mathrm{Bu}$ duruma basit bir örnek olarak işgörenlerin her zaman karşındakini bilgilendirmek için bir fikre veya bilgiye sahip olamayabileceklerini göstermektedirler (Dyne vd., 2003: 1363).

Bununla birlikte işgörenler çalıştıkları örgütler ve üstleri hakkında sessiz kalmaları gerektiğini ya da buna mecbur oldukları kararını bir anda vermemektedirler. Çalıştıkları örgütlerde onları bu davranışa iten birçok neden bulunmaktadır (Şehitoğlu, 2010: 43). Birçok çalışmada araştırmacılar, örgütsel sessizlik/işgören sessizliğinin nedenleri ve ne şekilde geliştiği üzerine odaklanmaktadırlar. $\mathrm{Bu}$ araştırmalar incelendiğinde örgütsel/işgören sessizliğinin nedenlerini üç başlık altıda toplamak mümkün gözükmektedir. Bunlardan ilki, örgüt içi ortamsal faktörlerin etkisiyle ortaya çıkan (genel olarak üst yönetim tutum ve davranışlarına bağlı olarak ortaya çıkmaktadır) ve işgörenlerin içsel değerlendirmelerince olumsuz olarak algılamış oldukları durumdur. İkincisi, işgörenlerin kişisel özellikleri ve demografik özelliklerini temsil eden kişisel faktörler başlı̆̆ıdır. Son faktör ise bir kısım örgüt yap1 ve özelliklerinden kaynaklanan durumu ifade etmektedir.

Milliken vd. (2003: 1469), organizasyon içerisinde çalışanların sessizleşme kararı vermesinde etkili olan faktörleri "kişisel özellikler", "organizasyonel özellikler" ve "ilişkilere dayanan özellikler" başlıklarında modelleyerek ifade etmektedirler. Morrison ve Milliken' e (2000) göre, sessizlik olgusu, organizasyon düzeyinde ortaya çıkar ve örgüt karakteristiklerinden etkilenir. Bu karakteristiklere örnek olarak karar verme, süreçler, yönetim süreçleri ve kültür gösterilebilir (Vakola ve Boudaras, 2005: 442). Örgütsel sessizlik olgusunu bir modelle ortaya koyan Morrison ve Milliken (2000), modelde örgütsel sessizliğin ana bileşenlerini ortaya koymalarının yanı sıra örgütsel düzeyde sessizliğin sosyal olarak yapılandırılmış bir olgu olduğuna açık bir biçimde vurgu yapmaktadırlar. $\mathrm{Bu}$ noktadan hareketle işgörenlerin neden sessizleştikleri üzerine yoğunlaşan bir kısım 
araştırmada, işgörenlerin algıladıkları korku ve endişeler nedeniyle içsel bir karar olarak sessizleştikleri iddia edilmektedir. Bu araştırmaların, yönetsel korkulara dayalı olarak işgörenlerin hataları ve işyeri sorunlarıyla ilgili açık konuşamamaları (Dyne vd., 2003: 1366; Alparslan ve Kayalar, 2012: 141), açık konuşanın bir risk yaratacağ1 inancı (Premeaux ve Bedian, 2003: 1537), misilleme korkusu (Brinsfield, 2009: 223; Kish-Gephart vd., 2009) korkunun neden olduğu sessizliğin alt düzeylerle sınırlı olmadığı (Detert ve Edmonson, 2006: 19), olumsuz biri olarak etiketlenme (Ashford ve Humphrey, 1997; Morrison vd., 2003: 1469), sürekli sorun çıkaran ve şikayetçi biri olarak görülme kaygısı (Milliken vd., 2003: 1473; Milliken ve Morrison, 2003: 1565), güven kayb1, sayg1 kayg1, destek ve kabul görmeme (Piderit ve Ashford, 2003: 1495), terfi edememe ve işini kaybetme (Milliken vd., 2003; Detert ve Edmonson, 2008; Dutton vd., 2002; Morrison vd., 2003; Piderit ve Ashford, 2003: 1495), izolasyon korkusu (Bowen ve Blockman, 2003: 1397; Milliken ve Morrison, 2003: 1565; Nikolaou vd., 2008: 668; Çakıc1 2007: 153), sosyal ilişkileri zedeleme kaygısı (Milliken vd., 2003: 1463; Çakıcı, 2010: 22) gibi korku ve kaygı temelli konular üzerine yoğunlaştı̆̆ görülmektedir.

Araştırmalar toplu olarak değerlendirildiğinde örgütsel sessizlik ve işgören sessizliği kavramlarının birbirlerinin yerlerine kullanıldığı ve dolayısıyla kavramlara ilişkin tam bir ayrımın yapılmadı̆̆ı görülmektedir. Aynı zamanda araştırmacıların örgütsel sessizlik ya da işgören sessizliği olarak kavramsallaştırmaya çalıştıkları olgunun tanımı üzerinde de bir fikir birliğinin olmadığı anlaşılmaktadır. Kimi araştırmacılar kasıtsız/amaçsız sessizlik hallerini de kavram içerisinde değerlendirirken (örn. Pinder ve Harlos, 2001; Bruneau: 1973); Van Dyne vd., 2003; Gephart vd., 2003; Kostiuk, 2012) diğer bir takım araştırmacıların sessizliği sadece bilinçli/amaçlı olarak değerlendirdikleri gözlenmektedir (örn. Premeaux ve Bedian, 2003; Bowen ve Blockman, 2003; Tangirala ve Ramanujam, 2008). 


\section{Z. UÇAR}

\section{ARAŞTIRMA METODOLOJISİ}

Alan Araştırması olarak tasarımlanan bu çalışma, öznelci bir bakış açısına sahiptir. Dolayısıyla çalışma kuramsal katkı yönünden değerlendirildiğinde, uygulamaya dönük öneri endişesi olmaksızın, betimleyici bir misyon taşımaktadır.

$\mathrm{Bu}$ araştırmada, Alan Araştırması yöntemi içerisinde nitel veri toplama teknikleri olarak değerlendirilen (Şencan, 2007: 131; Özdemir, 2010: 134) yar yapılandırılmış (semi structured) derinlemesine görüşme (deeply interview) ve odak grup veri toplama tekniklerinden yararlanılmıştır. Her iki veri toplama tekniğinde de görüşmeler yüz yüze gerçekleştirilmiştir. Nitel araştırmalarda sıklıkla kullanılan veri toplama aracı olan bu tekniklerin (DiCicco Bloom ve Crabtree, 2006: 315) araştırmacının bakış açısına göre şekillenebileceği düşünüldüğün de (Yıldırım ve Şimşek, 2011; Öztürk, 2011), araştırmada kullanılan veri toplama tekniğinin yorumsamacı (interpretive) bir bakış açısına sahip olduğu görülmektedir.

$\mathrm{Bu}$ araştırmanın evrenini, Türkiye'de faaliyette bulunan farklı örgüt yapıları içerisinde (özel sektör, kamu sektörü, yerel örgütler, sivil toplum örgütleri, siyasi örgütler) ve değişik kademelerde görev alan bireyler oluşturmaktadır. Farklı örgüt yapıları ve bu farklı örgüt yapıları içerisinde değişik kademelerden bireylerin farklı küme ve tabakalar oluşturması araştırmanın örnekleme türünün karmaşık bir görünüm sergilemesine neden olmaktadır. Dolayısıyla araştırma da örneklemeye ilişkin karar alınırken, birden fazla örnekleme türleri aynı anda kullanılmıştır:

1- Maksimum Çeşitlilik Örneklemesi (Amaçlı Örnekleme Yöntemi) (Yıldırım ve Şimşek, 2007: 107).

2- Kartopu ve Zincir Örnekleme (Amaçlı Örnekleme Yöntemi) (Yıldırım ve Şimşek, 2007: 107).

3- Kolay Ulaşılabilir Durum Örneklemesi (Amaçlı Örnekleme Yöntemi) (Yıldırım ve Şimşek, 2007: 107).

Araştırma soru formu Yıldırım ve Şimşek'in (2011) çalışmalarında ele almış oldukları dokuz kritere göre (örn. kolay anlaşabilecek sorular yazma, odaklı sorular 
hazırlama...) düzenlenmiştir. Belirtilen kriterlere göre dizayn edilen soru formu, konu hakkında bilgi sahibi olan iki akademisyene inceletilmiş ve pilot çalışma düzeyinde bir odak grup ve üç mülakatla sınandıktan sonra son halini almıştır.

Veri toplama sürecinde toplam üç araştırmacı görev almıştır ancak araştırma bulgularına dayalı tüm analizler tek araştırmacı tarafından yapılmıştır. Görüşmelerin başında tüm katılımcılara bazı demografik özelliklerinin yer aldığ 1 bir form doldurtulmuş ve bu formda katılımcıların tanınması için kendisini temsilen K-1, K-2, K-3 ...K-41 sembolleri atanmıştır. Ayrıca tüm görüşmeler elektronik ses kaydedici ile kayıt altına alınmıştır.

Tablo 1. Araştırma Katılımcıları Görüşme Süreleri

\begin{tabular}{|c|l|l|c|l|l|}
\hline $\begin{array}{l}\text { Katılımeı } \\
\text { Kodları }\end{array}$ & $\begin{array}{l}\text { Veri Toplama } \\
\text { Tekniği }\end{array}$ & $\begin{array}{l}\text { Görüşme } \\
\text { Süresi } \\
\text { (Dakika) }\end{array}$ & $\begin{array}{l}\text { Katılımcı } \\
\text { Kodları }\end{array}$ & $\begin{array}{l}\text { Veri Toplama } \\
\text { Tekniği }\end{array}$ & $\begin{array}{l}\text { Görüşme } \\
\text { Süresi } \\
\text { (Dakika) }\end{array}$ \\
\hline K-1 & Mülakat & $\mathbf{3 0 . 5}$ & $\mathbf{K - 2 1}$ & Odak Grup & 100 \\
\hline K-2 & Mülakat & $\mathbf{2 8}$ & K-22 & Odak Grup & 100 \\
\hline K-3 & Mülakat & $\mathbf{2 7 . 5}$ & $\mathbf{K - 2 3}$ & Odak Grup & 100 \\
\hline K-4 & Mülakat & $\mathbf{3 5 . 5}$ & $\mathbf{K - 2 4}$ & Odak Grup & 100 \\
\hline K-5 & Mülakat & $\mathbf{4 4 . 5}$ & $\mathbf{K - 2 5}$ & Odak Grup & 100 \\
\hline K-6 & Mülakat & $\mathbf{2 8}$ & $\mathbf{K - 2 6}$ & Odak Grup & 100 \\
\hline K-7 & Mülakat & $\mathbf{3 1 . 5}$ & $\mathbf{K - 2 7}$ & Odak Grup & 100 \\
\hline K-8 & Mülakat & $\mathbf{3 1}$ & $\mathbf{K - 2 8}$ & Odak Grup & 100 \\
\hline K-9 & Mülakat & $\mathbf{5 7 . 5}$ & $\mathbf{K - 2 9}$ & Odak Grup & 100 \\
\hline K-10 & Mülakat & $\mathbf{2 6}$ & $\mathbf{K - 3 0}$ & Mülakat & $\mathbf{2 4}$ \\
\hline K-11 & Mülakat & $\mathbf{3 0 . 5}$ & $\mathbf{K - 3 1}$ & Odak Grup & 112.5 \\
\hline K-12 & Mülakat & $\mathbf{3 0}$ & $\mathbf{K - 3 2}$ & Odak Grup & 112.5 \\
\hline K-13 & Mülakat & $\mathbf{4 1}$ & $\mathbf{K - 3 3}$ & Odak Grup & 112.5 \\
\hline
\end{tabular}


Z. UÇAR

\begin{tabular}{|c|l|l|c|l|l|}
\hline K-14 & Mülakat & $\mathbf{5 1 . 5}$ & K-34 & Odak Grup & 112.5 \\
\hline K-15 & Mülakat & $\mathbf{2 5 . 5}$ & K-35 & Odak Grup & 112.5 \\
\hline K-16 & Mülakat & $\mathbf{3 6 . 5}$ & K-36 & Odak Grup & 112.5 \\
\hline K-17 & Mülakat & $\mathbf{2 8}$ & K-37 & Odak Grup & 112.5 \\
\hline K-18 & Mülakat & $\mathbf{4 5}$ & K-38 & Odak Grup & 112.5 \\
\hline K-19 & Mülakat & $\mathbf{8}$ & K-39 & Odak Grup & 112.5 \\
\hline K-20 & Mülakat & $\mathbf{3 6}$ & K-40 & Mülakat & $\mathbf{2 8 . 5}$ \\
\hline K-21 & Odak Grup & 100 & K-41 & Mülakat & $\mathbf{5 1}$ \\
\hline
\end{tabular}

Araştırma, kamu örgütleri (genel idareye bağlı sağlık, eğitim, güvenlik, diyanet, diğer idari hizmetler ve yarı özerk akademik örgütler ve belediye), özel sektör (bankacılık, eğitim, ambalaj, film, reklam, sağlık, güvenlik hizmetleri vd.), sivil kurumlar (sendika, meslek örgütleri ve dernek) ve siyasi örgütlerde (siyasi partiler) hizmet veren 41 katılımcıyla gerçekleştirilmiştir.

Tablo 2. Örneklemin Demografik Özelliklerine Yönelik Bulgular

\begin{tabular}{|l|c|l|l|c|l|}
\hline Demografik Özellikler & Siklıklar & $\%$ & Demografik Özellikler & Siklıklar & $\%$ \\
\hline Cinsiyet & & & Yaş & & \\
\hline Kadın & 8 & 19,5 & $20-29$ aras1 & 10 & 24,25 \\
\hline Erkek & 33 & 80,5 & $30-39$ aras1 & 16 & 39,0 \\
\hline Toplam & 41 & 100,0 & $40-49$ aras1 & 9 & 22,0 \\
\hline Medeni Durum & & & $50-59$ aras1 & 6 & 14,75 \\
\hline Evli & 26 & & Toplam & 41 & 100,0 \\
\hline Bekar & 15 & 36,5 & Firma Deneyimi & & \\
\hline Toplam & 41 & 63,5 & 10 yıldan az & 30 & 73,25 \\
\hline Konum & & 100,0 & $10-19$ yıl aras1 & 4 & 9,75 \\
\hline
\end{tabular}


Dokuz Eylül Üniversitesi İktisadi ve İdari Bilimler Fakültesi Dergisi Cilt:31, Sayl:1, Yll:2016, ss. 311-342

\begin{tabular}{|l|c|c|l|c|c|}
\hline Mavi Yaka & 14 & 34,0 & $20-29$ yıl aras1 & 3 & 7,25 \\
\hline Beyaz Yaka & 27 & 66,0 & $30-39$ yıl aras1 & 4 & 9,75 \\
\hline Toplam & 41 & 100,0 & Toplam & 41 & 100,0 \\
\hline Ĕgitim Düzeyi & & & Toplam Deneyim & & \\
\hline Orta Öğretim & 4 & 9,75 & 10 yıldan az & 16 & 39,0 \\
\hline Ön Lisans & 5 & 12,25 & $10-19$ yıl aras1 & 10 & 24,25 \\
\hline Lisans & 21 & 51,25 & $20-29$ yıl aras1 & 6 & 14,75 \\
\hline Yüksek Lisans & 7 & 17,0 & $30-39$ yıl aras1 & 9 & 22,0 \\
\hline Doktora & 4 & 9,75 & Toplam & 41 & 100,0 \\
\hline Toplam & 41 & 100,0 & & & \\
\hline
\end{tabular}

Tablo 3. Katılımcıların Faaliyet Gösterdikleri Sektörlere Yönelik Bilgiler

\begin{tabular}{|c|c|c|c|c|c|c|c|c|}
\hline \multicolumn{6}{|c|}{ Kamu Sektörü $(\% \mathbf{5 3 , 6 6 )}$} & $\begin{array}{l}\text { Özel } \\
\text { Sektör }\end{array}$ & $\begin{array}{c}\text { Sivil } \\
\text { Toplum }\end{array}$ & $\begin{array}{c}\text { Siyasi } \\
\text { Örgütler }\end{array}$ \\
\hline \multicolumn{4}{|c|}{ Genel İdari Örgütler } & $\begin{array}{c}\text { Yarı Özerk } \\
\text { Kurumlar } \\
\text { (Belediye, Ünix.) }\end{array}$ & $\begin{array}{l}\text { Kamu Sektörü } \\
\text { Toplam }\end{array}$ & \multirow{3}{*}{24,43} & \multirow{3}{*}{12,20} & \multirow{3}{*}{9,75} \\
\hline Eğitim & Sağlık & Güv. & Diğer & \multirow[t]{2}{*}{26,83} & \multirow[t]{2}{*}{53,66} & & & \\
\hline 7,32 & 7,32 & 4,87 & 7,32 & & & & & \\
\hline
\end{tabular}

Araştırma örnekleminin büyüklüğü herhangi bir istatistikî bir çalışmayla hesaplanmamıştır. Nitel araştırmaların doğası gereği oldukça maliyetli ve zaman alıcı oluşu nedeniyle optimal bir denge sağlanmaya çalışarak ve araştırma konusuyla ilgili elde edilen veriler tekrarlanınca ya da diğer bir ifade ile farklı bilgiler çıkmamaya başlayınca araştırmanın veri toplama süreci sonlandırılmıştır.

\subsection{Verinin Düzenlenmesi ve İçerik Analizi}

$\mathrm{Bu}$ aşamada odak grup görüşmeleri ve derinlemesine görüşmeler sonunda elde edilen ham veriler, anlam bütünlügünün sağlaması ve içerik analizine uygun hale getirilmesi için ilk olarak metne dönüştürülmüş ve sonrasında çözümlenmeye 


\section{Z. UÇAR}

başlanmıştır. $\mathrm{Bu}$ şekilde düzenlenen veriler içerik analizine tabi tutulmuş ve birbirleriyle ilişkili olduğu belirlenen ifadeler sınıflandırılarak belirli temalar altında birleştirilmiştir.

\section{BULGULAR VE TARTIŞMA}

\subsection{Karakteristik Özelliklerinin Sessizlik Olgusuna Etkisi}

Karakteristik özelliklerin açık bir biçimde konuşup konuşmama kararı verme üzerindeki etkisi, araştırma bulgularına dayalı olarak Tablo 4 üzerinden tartışılmıştır. $\mathrm{Bu}$ amaçla katılımcıların kullanmış oldukları örnek ifadeler, bu ifadelerin ilişkili olduğu kavramlar ve sıklıkları Tablo 4'te düzenlenmiştir.

Tablo 4'te yer alan birinci ve ikinci sütunlara ilişkin kişinin, yaşam olaylarıyla mücadele etme tarzını tanımlayan ve bir kişilik özelliği olarak değerlendirilen "Kontrol Odağı" kavramının ön plana çıktığı değerlendirilmektedir. Kavram, kişinin mücadele tarzına yönelik referans alanlarını tanımlamaktadır. Bireye genellenmiş kontrol beklentilerinin iç odaklılık ve dış odaklılık boyutları üzerindeki konumu üzerinden; pekiştiricilerin bireyin kendine atfettiği ya da dışındaki güçlerin (şans, kader vb.) kontrolünde olduğuna yönelik genel beklentisi ya da inancını yansıtmaktadır (Erol vd., 2000: 149). İç kontrol odaklı (İKO) kişiler kendi yaşamlarını üzerinde kontrol güçleri olduklarına inanmaktadırlar. Buna karşın İKO’lu kişilerin karşııtları olarak görülen Dış Kontrol Odaklı (DKO) kişiler kendi kaderlerinin büyük ölçüde kendi kontrolleri dışında olduğuna inanmaktadırlar ve bu kişilere göre kendilerini etkileyen yaşamış oldukları olaylar kader, şans ya da diğer güçler tarafindan belirlenmektedir (Premeaux ve Bedian: 2003: 1542). Rotter (1992) DKO’yu öğrenilmiş çaresizlikle ilişkili olduğunu belirtirken, İKO'yu ise örneğin planlama, başa çıkma, sebat ve diğer sorun çözme teknikleri gibi daha proaktif kavramlarla ilişkili olduğunu belirtmektedir (Premeaux ve Bedian, 2003: 1542).

Rotter (1992: 127) ayrıca Batı kültürlerinin İKO’lu kişilere vurgu yaptığını belirttiği çalışmasında, İKO’lu kişilerin öz yetkinlik algılarının yüksek olduğuna ve bu durumunda başarma arzularını güçlendirdiğine dikkat çekmektedir. Buna karşın 
Doğu kültürlerinde insanlar durumun olumlu ya da olumsuz olmasına bakmaksızın kader, şans, tesadüf ya da farklı güçler tarafından kontrol edilebildiklerine inanmaktadırlar. Premeaux ve Bedian (2003: 1453) çalışmalarında İKO’nun açık konuşma ile pozitif yönlü bir ilişkisi olduğunu ortaya koymaktadırlar. Yazarlar tarafından yapılan bu tespit, iç kontrol odaklı kişilerin çalıştıkları ortamda gelişen durumlara ilişkin kendi kontrollerinin olduğunu düşünmelerine neden olmaktadır. Dolayısıyla bu kişiler, durumları değiştirebilme kabiliyetlerinin olduğuna inandıklarından konuşmaya daha eğilimli olacaklardır.

Kişilerin yaşamla mücadele tarzını ele bir diğer kişilik özelliğinin de "Benlik Saygısi/Öz Saygı" (Self Esteem) olduğu anlaşılmaktadır. Özoğlu (1976) benlik kavramını, kişinin davranış şeklini ortaya koyan, kişisel değer, amaç ve ideallerinin dinamik bir organizasyonu olarak tanımlamaktadır. Bu bakımdan benlik bireyin kendi oluşunu, içinde yaşamış olduğu çevreden ve diğer benliklerden farklılaştıran temel ve belirgin karakteristiklerinin birey tarafından soyutlanmış halidir (aktaran Şekercioğlu ve Güzeller, 2012: 216). Bu yönü ile bireyin kendisine ve çevresine ait algılarını geliştirmesinde ve bu geliştirmiş olduğu algıları sonucuna göre hareket etmesinde bireyi motive etmektedir. 
Z. UÇAR

Tablo 4. Katılımcıların Karakteristik Özellikleri Bağlamında Kullanmış Oldukları İfadeler Ve Sıklıkları

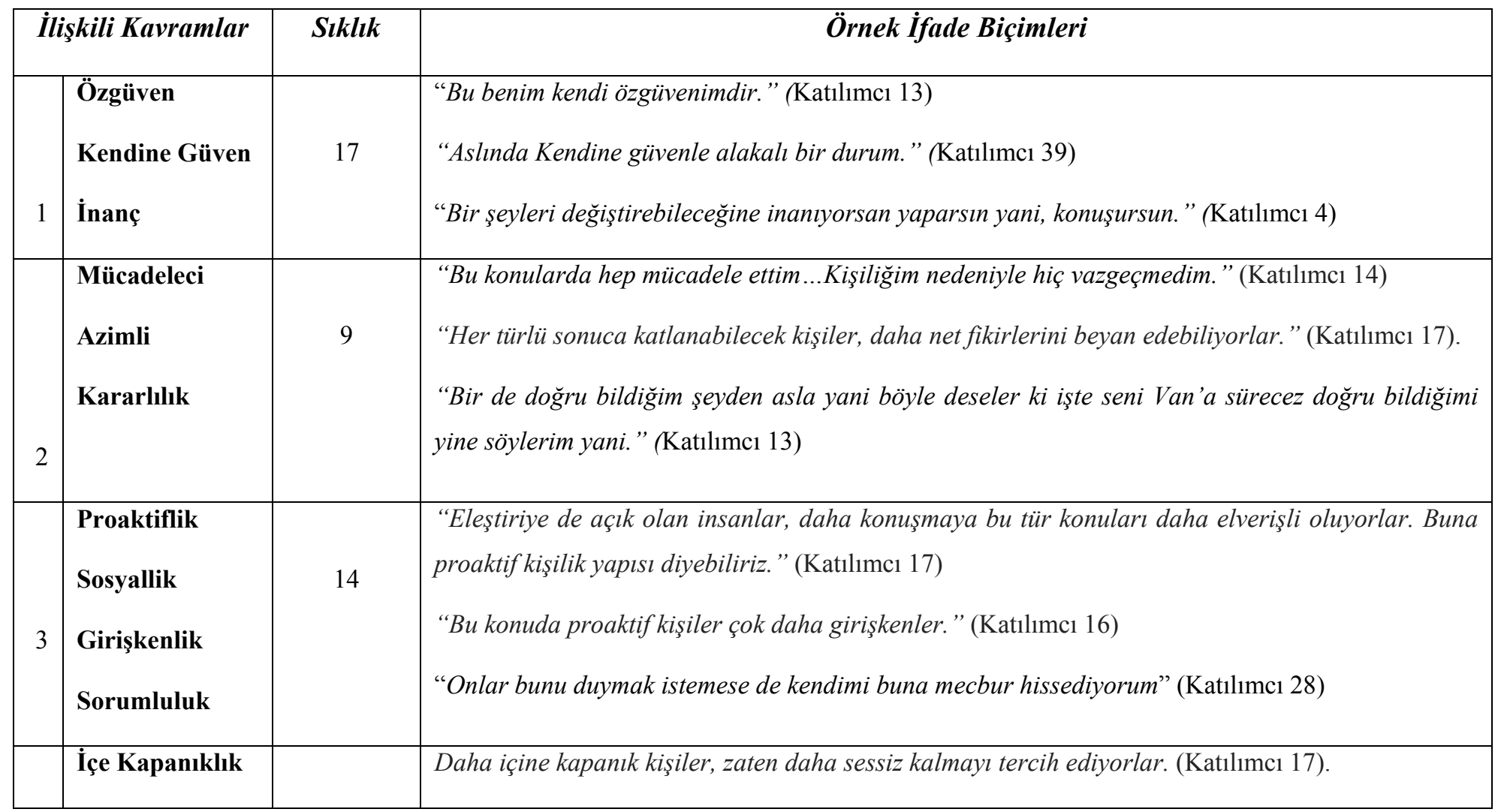


Dokuz Eylül Üniversitesi İktisadi ve İdari Bilimler Fakültesi Dergisi Cilt:31, Sayl:1, Yll:2016, ss. 311-342

\begin{tabular}{|c|c|c|c|}
\hline 4 & Ketumluk & 9 & $\begin{array}{l}\text { Bazıları konuşmayı sevmiyor, biraz ketum oluyor her nedense. (Katılımcı 9) } \\
\text { “Açıkçası her konuda çok konuşmayı sevmem. ... Bu benim kişiliğimle alakalı.” (Katılımcı 34) }\end{array}$ \\
\hline 6 & $\begin{array}{l}\text { Prososyallik } \\
\text { İyi Niyetlilik }\end{array}$ & 14 & $\begin{array}{l}\text { "Hakikaten ben ispiyon etmeyi sevmem zaten.” (Katılımcı 7). } \\
\text { “Zarar görülmeyecek bir konuysa bir şekilde koruruz.” (Katılımcı 1) } \\
\text { “Bana zarar vermeyecekse kesinlikle söylemem.” (Katılımcı 23) } \\
\text { "Etik bakış açısından dolayl, kurum kültürü, kurum prestiji kurum saygınlığının düşmemesi belki } \\
\text { halk gözünde belki ondan dolayı.” (Katılımcı 17) }\end{array}$ \\
\hline
\end{tabular}




\section{Z. UÇAR}

Literatürde benlik saygıs1, genel olarak yüksek veya düşük olarak açıklanmaktadır (Hamarta vd., 2009). Öz benlik algısı yüksek olan bireyler sosyal ilişkilerinde daha girişimci, daha güvenli ve daha atak kişilerdir. Düşük öz benlik algısına ilişkin Rosenberg (1965) bu tür düşük benlik algısına sahip olan kişilerin sosyal etkileşimlerinde daha çok sorunlarla karşılaştıklarını, daha fazla tehdit algıladıklarını ve eleştiriye duyarlı olduklarını aktarmaktadır. Ayrıca düşük öz benlik algısı biriylerin çevreye uyumumda ve doğal olarak ilişimde de problemler yaşamalarına neden olabilecektir (aktaran Hamarta ve Demirtaş, 2008: 241). Premeaux ve Bedian öz benlik ve kişilerin örgütsel değiş̧ikliklerle başa çıkabilmesi arasında pozitif yönde bir ilişki olduğunu belirttikleri çalışmalarında, yüksek düzeyde benlik saygısına sahip bireylerin açıkça konuşma davranışı sergilemeye daha eğilimli olduklarını, bu durumun aksine düşük düzeyde benlik saygısına sahip olan bireylerin ise açıkça konuşma sonucunda oluşabilecek olumsuzluklarla karşı karşıya kalmamak için açıkça konuşmaktan kaçındıklarını belirtmektedirler (Premeaux ve Bedian, 2003: 1543).

Tablo 4'ün üçüncü ve dördüncü sütunları incelendiğinde katılımc1ların genel olarak içe kapanık kişilerin dışa dönük kişilerden daha fazla sessiz kaldıklarını belirtmektedir. Literatürde de bu bulguyu destekleyen araştırmalar görülmektedir. LePine ve Van Dyne (2001) yapmış oldukları çalışmada büyük beş kişilik özelliklerinin her biri ve çalışma grupları arasındaki ilişkiyi araştırmışlardır (Morrison, 2011: 192). Yine tablo 4'ün üçüncü satırında yer alan sorumluluk kavramına ilişkin, LePine ve Van Dyne, kişilerin sahip oldukları sorumluluk düzeyi ve dışa dönüklük düzeyinin yüksek olması ile seslilik arasında pozitif bir ilişki saptamışlardır. Sorumluluk düzeyi yüksek bireylerin çevrelerindeki durumların nasıl değiştiği hakkında konuşmalara dahil olmaya gönüllü olduklarını ancak dişa dönük kişilerin ise üstleriyle açık çok rahat bir şekilde açı konuştuklarını belirtmektedirler (Morrison, 2011: 192).

Tablo 4'ün altıncı satırındaki katılımcı ifadelerinden de anlaşılacağı üzere bir kısım katılımıının iyi niyeti olarak sessiz kaldıkları anlaşılmaktadır. Örgütsel sessizlik yazını içerisinde de sıkça ele alınan bu olgu prososyal davranma niyeti 
olarak adlandırılmaktadır. Dyne vd. (2003) yapmış oldukları çalışmada prososyal davranma niyetini “örgütsel vatandaşlık davranışı” ile ilişkilendirmişlerdir. Yazarlar örgütsel vatandaşlık davranışının boyutlarından biri olan centilmenlik (sportmenship) ile prososyal davranma niyeti arasında yakın bir ilişki olduğunu belirtmektedirler. Brinsfield (2009: 146) prososyal davranma niyetinin bireyin örgütü koruma ve diğer çalışanları koruma güdülerinden kaynaklı olarak iki şekilde ortaya çıktığını belirtirken, Dyne vd. (2003: 1368), bu güdülere sahip kişilerin örgütlerine ve iş arkadaşlarına zarar verecek durumları bilerek ve bilinçli bir şekilde sakladıklarını ifade etmektedir.

İşgörenlerin sergilemiş oldukları prososyal sessizlik davranışına yönelik elde edilen bulguların literatürle yüksek oranda paralellik göstermesinin yanı sıra bir takım çarpıcı sonuçlarda ortaya çıkmıştır. Bunlardan ilki, arkadaşlarının zarar görmemesi için prososyal sessizlik davranışı sergileyen işgörenin, sessiz kalınan durumun sonuçlarından zarar görmeyecek bir konumda olması gerektiğidir. İşgörenler prososyal anlamda sessiz kalmaları sonucu zarar göreceklerine inanıyorlarsa, böyle bir davranış sergilemeyeceklerini belirtmektedirler. Ayrıca işgörenlerin bu durumu kişisel özellikleriyle açıklarken iş arkadaşlarına karşıda kendilerini sorumlu hissetmektedirler.

Araştırma bulguları içerisinde sıkça görülmemesine karşın makyevelist kişilik özelliğinin de sessizliğe neden olduğu anlaşılmaktadır. $\mathrm{Bu}$ sessizlik biçimi, işgörenin stratejik bir bilinçle kendileri için avantaj sağlayacak bilgileri kasıtlı olarak gizlemesi ve gerçek düşünce ve tutumlarını gizleyerek yine kendilerine avantaj sağlamak için farklı bir duruş sergilemeleri olarak tanımlanabilir. $\mathrm{Bu}$ kavramın Snyder'in (1970) ortaya koymuş olduğu Self Monitoring (Kendini Uyarlama) Teorisi’yle yakın ilişkili olduğu düşünülmektedir. Özellikle de kendini uyarlama düzeyleri yüksek olan bireylerde görülme olasılığı daha yüksek olan bu davranış biçimi, stratejik amaçlar içerebilmektedir.

Knoll ve Dick (2013) yapmış oldukları çalışmada sessizlik odaklı diğer çalışmalardan farklı olarak Fırsatçı Sessizlik boyutunu ortaya koymaktadırlar. Knoll ve Dick (2013: 351) işgörenlerin bazen kendileri için avantaj sağlayacak 


\section{Z. UÇAR}

bilgileri kasıtlı olarak gizleme eğiliminde olduklarını belirterek Fırsatçı Sessizliği, işgörenlerin diğerlerinin zarar göreceğini bile bile iş ile ilgili düşünce, bilgi ya da fikirlerini kendilerine avantaj sağlaması amacı ile stratejik olarak gizlemeleri biçiminde tanımlamaktadırlar. Ayrıca Harlos ve Pinder (1999) ve Harlos (2004) yapmış oldukları çalışmalarda, sessizliğin işgörenler tarafından stratejik olarak kullanılabilineceğine dikkat çekmektedirler. Yazarlar kavramsallaştırmaya ilişkin Oliver E. Williamson, 1985 yılında yayınladığı "The Economic Institutions of Capitalism" adlı eserinde "hile ile kişisel çıkar arama" (self-interest seeking with guile) konusu üzerine odaklandıklarını belirtmektedirler. Williamson (1985: 47) hile ile kişisel çıkar arama kavramını, yalan söyleme, çalma ve dedikoduyla ilişkilendirmektedir. Knoll ve Dick (2013) ortaya çıkması mümkün olan çeşitli fırsatçılık davranışlarına karşın kendilerinin genel olarak yanıltma, gizleme ve zihin karıştırma gibi bilgi saklama ve eksik ve/veya çarpıtılmış bilgi aktarma konuları üzerine yoğunlaştıklarını belirtmektedirler.

$\mathrm{Bu}$ araştırma bulgularında çıkmayan ama salt psikolojik alandaki klinik çalışmalarla ortaya çıkabileceği değerlendirilen diğer bir özellikte kişisel iletişim endişesidir. İletişim endişesi McCroskey (1970) tarafindan geniş tabanlı bir iletişim korkusu olarak tanımlanmaktadır. Yüksek düzeyde bu endişeye sahip olan kişiler iletişiminin sonuçlarına ilişsin olumsuz duygulara kapılmaktadırlar ve mümkün oldukça iletişime girmekten kaçınmaktadırlar. Ayrıca bu kişiler konuşmaya zorlandıklarında çeşitli endişe verici duygular içinde açı çekmektedirler (aktaran Pinder ve Harlos, 2001: 355). Çakıcı (2010: 223) iletişim kaygısı yüksek olan bireylerin sessizliğe karşı kişisel yatkınlığının olduğunu belirtmektedir.

Literatürde bireylerin sessiz kalmalarıyla ilgili değinilen diğer kişilik özelliklerinin duygusallık ve uyumlu kişilik düzeyleri olduğu görülmektedir. Duygu düzeyi yüksek olan bireyler, diğerleri hakkında konuşurken kendilerini gergin hissetmekteyken, uyum düzeyi yüksek olan bireyler ise bir şeyleri değiştirmektense mevcut durumun devamını devam ettirme eğilimi göstermektedirler (Morrison, 2011: 392). Morrison'un bulgusundan hareketle, duygu düzeyi yüksek bireylerin olumsuz durumları aktarırken zorlandıkları bu 
nedenle bu zorluklarla karşılaşmamak için açık konuşmaktan çekinebilecekleri, uyum düzeyi yüksek olan bireylerin ise çoğunlukla birlikte bir hareket tarzı geliştirme çabası içinde oldukları ve statükonun devamının kendileri açısından güven hissi yarattığını düşündükleri için farklı fikir veya endişelerini aktarmaktan kaçınabilecekleri düşünülmektedir.

\section{2. İşgörenlerin Demografik Özelliklerinin Sessizlik Olgusuna Etkisi}

O’Reilly vd. (1989) yapmış oldukları çalışmada demografik olarak homojen olan grupların sosyal anlamda bütünleşmelerinin daha olası olduğunu belirtmektedirler. Ancak bu gruplar içerisindeki benzeşmenin yüksek oluşu açık ve özgür konuşmayı cesaretlendirmesine karşın, bu benzerlikleri paylaşan insanlar sık sık benzer şeyleri düşünmekte ve benzer fikirlere sahip olmaktadır. (aktaran Bowen ve Blockman 2009: 1398)

Özellikle sessizlik çalışmalarının başlangıcı olarak kabul edilen Hirsman'ın (1970) çalışmasından 2000'li yıllara kadar, sessizlik çalışmaların örgütsel bağlamda evrimleştiği süreç sonunda, tam olarak yeni paradigmayı yansıtan ve örgütsel sessizlik kavramı üzerinden yeni bir yazın olanı oluşturan Morrison ve Milliken (2000) tarafından yapılan çalışmada, demografik özelliklerin sessizlik davranışı üzerinde etkili olduğu ifade edilmektedir. Ancak literatür incelendiğinde yazına katkı sağlayan bir çok çalışmada demografik özellikler ile sessizlik arasındaki ilişkiye yer verilmediği de dikkate değer önemli bir ayrıntı olarak karşımıza çıkmaktadır (örneğin, Premeaux ve Bedeian, 2003; Amah ve Okafor, 2008; Vakola ve Bouradas, 2005; Liu vd., 2009; Huang vd., 2005). 
Z. UÇAR

Tablo 5. Katılımcıların Demografik Özelliklerine Kullanmış Oldukları İfadeler ve Sıklıkları

\begin{tabular}{|c|c|c|c|}
\hline & $\begin{array}{c}\text { Demografik } \\
\text { Özellikler }\end{array}$ & Sıklık & Örnek Ifade Biçimleri \\
\hline 1 & Cinsiyet & 37 & $\begin{array}{l}\text { “...Daha sesliler. .” (Katılımıı 13). } \\
\text { “Kadınlar daha sesliler.” (Katılımcı 20). } \\
\text { “Bayanlar evet, her ne kadar Türk toplumunda evet bayanlara açı̆̆ız ve saire dense de bayanlar her } \\
\text { zaman öte kalıyor. Bayanların fikirlerine çok değer verilmiyor. ... Kültürel açıdan da özellikle işs } \\
\text { yaşantısında bayanların fikirlerine çok değer verilmez ya da erkekler hep bunu düşünür.” (Katılımc1 17) } \\
\text { “Pek fazla konuşturulmuyoruz.” (Katılımcı 4) } \\
\text { "Bu ülkede kadın olmak bir handikap” (Katılımcı 15). } \\
\text { "Yani ben cinsiyetin bu konuda bir fark yaratabileceğini düşünmüyor ve de görmedim.” (Katılımacı 25). }\end{array}$ \\
\hline 2 & Eğitim Düzeyi & 37 & $\begin{array}{l}\text { "Eğitimliler daha fazla mesela, oradaki üniversite mezunlarl çok konularl daha fazla dile getirirler.” } \\
\text { (Katılımc1 1) } \\
\text { "Eğitim düzeyi itibariyle bence kişiler daha kolay fikirlerini, kendilerini ifade edebiliyorlar, eğitim } \\
\text { düzeyini arkalarına alarak." (Katılımc1 11) } \\
\text { "Eğitim bu nedenle önemli çünkü kendinize güveniniz artıyor." (Katılımc1 19) } \\
\text { "Şimdi bakıyoruz eğitimli üyelerimiz fikirleri daha rahat ifade ediyor.” (Katılımc1 10). }\end{array}$ \\
\hline
\end{tabular}


Dokuz Eylül Üniversitesi İktisadi ve İdari Bilimler Fakültesi Dergisi Cilt:31, Sayl:1, Yll:2016, ss. 311-342

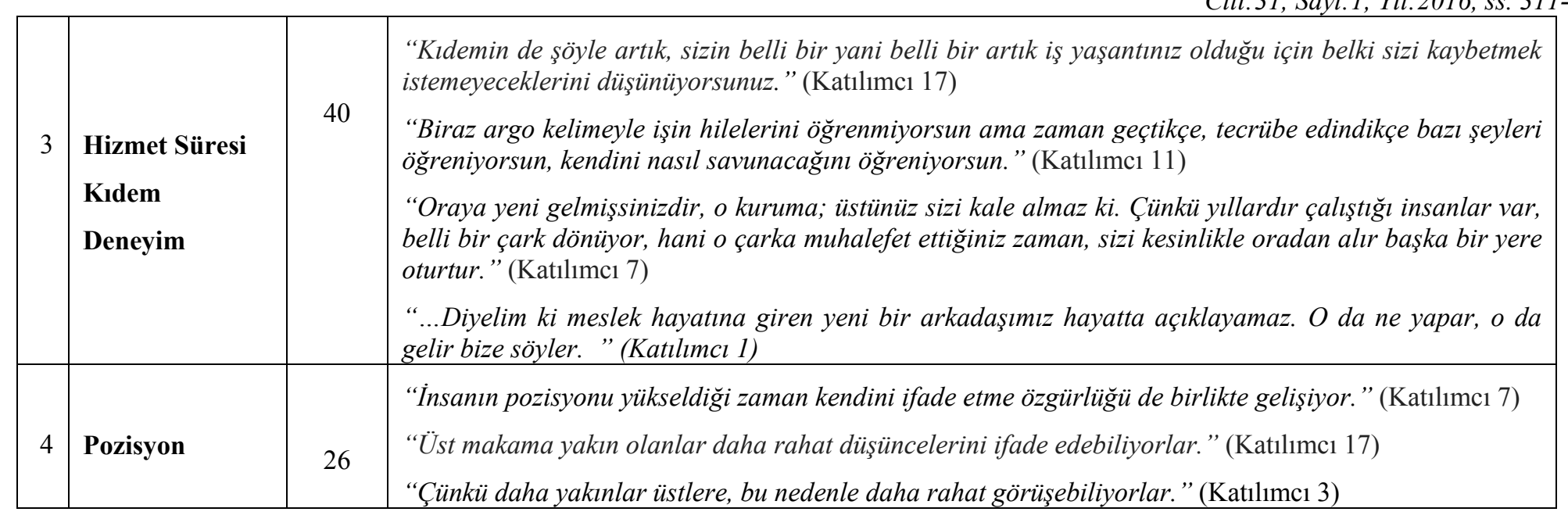




\section{Z. UÇAR}

Tablo 5'in ilk satırındaki ifadeler incelendiğinde cinsiyet ve sessizlik arasında bir ilişkiyi açıklayan ifadelerin karmaşık bir görünüme sahip olduğu anlaşılmaktadır. Nitekim farklı ampirik çalışmalarda da bu sonuç ortaya çıkmaktadır. Örneğin, Kahveci (2010: 92) tarafından gerçekleştirilen çalışmanın sonuçlarına göre, kadınların erkeklere nazaran daha fazla sessiz kaldıklarını ve sorunlarını daha az dile getirdikleri belirtilmekte iken, Özdemir ve Uğur (2013: 271) yapmış oldukları çalışmada cinsiyetle ve sessizlik arasında anlamlı bir fark bulunamamıştır.

Araştırma bulgularındaki bir diğer önemli ayrıntı ise kimi katılımcıların kadınların erkeklerden daha fazla açık konuştuklarını ifade etmiş olmalarıdır. Ancak bu yönde görüş belirten katılımcıların tümünün de kadın olmaları dikkat çekicidir.

Bununla birlikte katılımcıların bir kısmımın işyerlerinde kadınların sessiz kalmasını ya da sessizleştirilmelerini makro düzeyde kültürel değerlerle açıklamaya çalıştıkları görülmüştür.

Tablo 5'in ikinci satırı incelendiğinde, katılımcıların genel olarak eğitim düzeyi ve işgörenlerin sessiz kalmaları arasında ters yönde ilişki olduğunu savundukları görülmektedir. Nitekim literatürde de bu bulguyu destekleyen çalışmalar mevcuttur (örn. Tayfun ve Çatır, 2013: 128; Özdemir ve Uğur, 2013: 272).

Eğitim düzeyi ve sessizlik olgusuna ilişkin ortaya çıkan önemli bir bulgu ise eğitimin kişiye güven hissi verdiğine ilişkindir. Eren'in de (2012: 55) belirtmiş olduğu gibi eğitim, bireyi toplumla girişmiş olduğu iletişimde güçlü kılan, dış dünya ile bağlantı kurmasını kolaylaştıran, gerek kendi gerekse de diğerlerinin haklarını savunmasını sağlayan ve birçok mecrada kişinin gelişimine katkıda bulunan bir faktördür. Nitekim araştırma bulgumuz bu tanımı destekler niteliktedir.

Yine Tablo 5'in üçüncü satırı incelendiğinde katılımc1ların hizmet süresi/kıdem ve işgörenlerin açık konuşmaları arasında sıklıkla ilişki kurdukları görülmektedir. Katılımcılar genel olarak kıdem veya deneyim olarak ifade etmiş oldukları değişkenin kişinin sessiz kalma davranışını azalttığını belirtmişlerdir. Elde edilen 
bulguların, bu noktalarda literatürle de paralellik gösterdiği anlaşılmaktadır (Milliken vd., 2003; Burris vd., 2008; Detert ve Burris, 2007; Tangirila ve Ramanujam, 2008; Kahveci, 2010; Tayfun ve Çatır, 2013). Bununla birlikte katılımcıların durumu açılarken nedensellik ilişkilerini kurdukları da gözlemlenirken, bu ilişkiyi korkular üzerinden ele aldıkları anlaşılmaktadır.

Hizmet süresi ile ilgili olarak bir katılımcının, tecrübe sahibi ve deneyimli işgörenlerin ikame edilebilirliği üzerinden konuyu değerlendirmesi oldukça dikkat çekicidir. Aslında bu durum belirli bir süre örgüte hizmet ederek rüştünü ispat etmiş çalışanların örgütlerine fazladan bir şeyler katma duygularıyla da ilişkilendirilebilir. Nitekim Morrison ve Milliken (2011: 393), kıdemli çalışanların çalışma süresi az olanlara oranla daha fazla açık konuşabildiklerini belirtmektedirler. Araştırmacılar bu durumun temel nedeni olarak, hizmet süresi daha yüksek olan kişilerin kendi organizasyonlarına karşı daha büyük bir yatırım duygusu içerisinde olduklarını öne sürmektedirler.

$\mathrm{Bu}$ durumlardan farklı olarak hizmet süresi düşük olan işgörenlerin yatay düzlemde hizmet süresi yüksek olan çalışanlar üzerinden açılabildikleri anlaşılmaktadır. $\mathrm{Bu}$ noktada yeni işgören, hizmet süresi fazla olan işgörenlerin geliştirmiş oldukları sosyal ilişkileri kullanarak açılmaya çalıştıkları sonucu çıkmaktadır. Aslında bu durum örgütsel düzeydeki sessizlik araştırmalarının ne kadar girift bir yapıda olduğunu da ortaya koymaktadır.

Tablo 5'in dördüncü satırındaki katılımcı ifadeleri incelendiğinde genel olarak katılımcılar, çalışanların üst pozisyonlara yükselmeleriyle birlikte kendilerini daha rahat ifade edebildiklerini belirtmektedirler. Literatürde de bu bulguyu destekleyen bir araştırmanın olduğu görülmüştür. Özdemir ve Uğur (2013: 272-273) temel olarak demografik değişkenler ile algılanan ses ve sessizlik arasındaki ilişkiyi araştırmış oldukları çalışmada, pozisyon ve sessizlik arasında anlamlı bir ilişki olduğunu bulgulamışlardır.

Hofstade (1991) yapmış olduğu çalışmada Türkiye'nin kültürler arası farklılıklar temelinde yüksek düzeyde güç mesafesi olan toplumlar arasında yer 


\section{Z. UÇAR}

aldığını belirtmektedir. Van De Vliert ve Van Der Vegt (2005) araştırmalarında, farklı hiyerarşik kademelerde bulunan işgörenlerin sessiz kalma davranışlarının güç mesafesi ile ters yönde ilişkili olduğunu belirtmektedirler. Bu bağlamda Üçok ve Torun'un da ( 2015: 34) belirtmiş oldukları gibi yüksek güç mesafesinin görüldüğü toplumlarda, işgörenlerin üst yönetime görüşlerini iletme ve yöneticilerine karşı çıkma eğilimlerinin daha düşük olduğunu ve dolayısıyla çalışanların sessizlik davranışına daha çok yöneldiklerini söylemek mümkündür.

Bununla birlikte birbirlerine yakın hiyerarşik pozisyonlar arasındaki yüz yüze olan ilişkiler sonucu oluşan daha yakın sosyal ilişkilerin de bunu etkilediği düşünülmektedir.

\section{SONUÇ}

Araştırma bulgularına bağlı olarak kişisel faktörler ana teması altında işgörenlerin sahip oldukları bazı karakteristik ve demografik özelliklerin, onların sessiz kalma davranışı sergilemelerinde etkisinin olduğunu ortaya konmuştur. Özellikle açık konuşmadan çekinmediklerini belirten katılımcıların genellikle özgüven, kararlılık, mücadeleci kişilik yapısı gibi yaşam olaylarıyla mücadele etme tarzlarını ifade eden kavramlar kullandıkları görülmüştür. İlgili yazınlara dayalı olarak yapılan incelemeler, katılımcılar tarafindan belirtilen bu kavramlarla Kontrol Odağı, Benlik Saygısı, Dışa Dönüklük-İçe Dönüklük ve Sorumluluk Düzeyi kavramlarının yakın ilişkili olduğu ortaya koymuştur. Kontrol Odağı Kavramı, kişinin mücadele tarzına yönelik referans alanlarını tanımlarken, kişilerin genellenmiş kontrol beklentilerinin iç odaklılık ve dış odaklılık boyutları üzerindeki konumu; pekiştiricilerin bireyin kendine atfettiği ya da dışındaki güçlerin (şans, kader vb.) kontrolünde olduğuna yönelik genel beklentisi ya da inancını yansıtmaktadır. Literatürde yüksek ve düşük olarak ele alınan Benlik Saygısı kavramı ise bireylerin yaşamla mücadele tarzını yansıtan kişisel değer, amaç ve ideallerinin dinamik bir organizasyonu olarak tanımlamaktadır. Öz benlik algısı yüksek olan bireyler sosyal ilişkilerinde daha girişimci, daha güvenli ve daha atak bir görüntü sergilemektedirler. Buna karşın düşük öz benlik algısına sahip olan kişilerin sosyal etkileşimlerinde daha çok sorunlarla karşılaştıklarını, daha fazla 
tehdit algıladıkları ve eleştiriye duyarlı oldukları anlaşılmıştır. Bununla birlikte Dışa Dönüklük-İçe Dönüklük kavramları da yüksek düşük Öz Benlik Kavramlarıyla oldukça yakın bir bakış açısına sahiptir. Dışa dönük işgörenler üstleriyle rahat bir şekilde konuşabildiklerini belirtmişlerdir. Son olarak Sorumluluk düzeyi yüksek bireylerin çevrelerindeki durumların nasıl değiştiği hakkında konuşmalara dahil olmaya gönüllü oldukları söylenebilir

Sessiz kalma davranışına bağlı olarak işgörenlerin prososyal davranma niyetiyle sessiz kaldıkları da anlaşılmıştır. İşgörenler bazen iş arkadaşlarının zor durumda kalmaması bazen de dışarıda iş yerini kötülememek ya da itibarını sarsmamak için sessiz kalmayı seçmektedirler. Bununla birlikte makyevelist kişilik özelliğine sahip bireylerin de stratejik bir bilince dayalı olarak sessiz kaldıkları görülmüştür.

İşgörenlerin sessiz kalmalarına neden olan bir diğer faktör Kişisel Özellikler teması altında etiketlenen demografik özellikler temasıdır. $\mathrm{Bu}$ tema altında Cinsiyet, Eğitim Düzeyi, Pozisyon, Kıdem başlıkları kodlanarak incelenmiştir. Katılımcılar, literatüre de paralel olacak şekilde cinsiyetin çalışan bireylerin sessiz kalmama kararı vermelerine etkisini belirtirken karmaşık bir görüntü sergilemektedirler. Eğitim düzeyi arttıça işgörenlerin daha açık bir biçimde konuştukları ifade edilmiştir. Hizmet süresi ve işgörenlerin sessizleşmeleri arasındaki ilişkiye yönelik katılımcı ifadeleri incelendiğinde, bu iki faktör arasında sıklıkla ilişki kurulduğu görülmektedir. Katılımcılar genel olarak kıdem veya deneyim olarak ifade etmiş oldukları değişkenin, kişinin sessiz kalma davranışını azalttığını belirtmişlerdir. Pozisyona ilişkin olarak katılımcılar, çalışanların üst pozisyonlara yükselmeleriyle birlikte kendilerini daha rahat ifade edebildiklerini belirtmektedirler.

\section{KAYNAKÇA}

AFŞAR, L. (2013), Örgütsel Sessizlik ve Örgütsel Güven İlişki: Konuya İlişkin Bir Araştırma, İstanbul Üniversitesi Sosyal Bilimler Enstitüsü Hastane ve Sağlık Kuruluşlarında Yönetim Bilim Dalı, Yayınlanmamış Yüksek Lisans Tezi, İstanbul. 


\section{Z. UÇAR}

ALPARSLAN, A. M., KAYALAR, M. (2012), "Örgütsel Sessizlik: Sessizlik Davranışları, Örgütsel ve Bireysel Etkileri”, Mehmet Akif Ersoy Üniversitesi Sosyal Bilimler Enstitüsü Dergisi, 4(6), 136-147.

AYKANAT, T. (2012), "Bilginin Malzeme olarak Kullanıldığı Sanatlar ile Metinlerarasılık Arasındaki Bağlantılar”, International Journal of Social Science. $5(4), 11-31$.

BELL, M. P., ÖZBILGIIN, M. F., BEAUREGARD, T. A., SÜRGEVIL, O. (2011), "Voice, Silence, and Diversity in 21st Century Organizations: Strategies for Inclusion of Gay, Lesbian, Bisexual, and Transgender Employees", Human Resource Management, 50(1), 131-146.

BOWEN, F., BLACKMON, K. (2003), "Spirals of Silence: The Dynamic Effects of Diversity on Organizational Voice", Journal of Management Studies, 40(6), 1393-1417.

BRINSFIELD, C. T. (2009), Employee Silence: Investigation of Dimensionality, Development of Measures, and Examination of Related Factors, Ohio State University, Yayınlanmamış Doktora Tezi, Ohio, USA.

CLAPHAM, S. E., COOPER, R. W. (2005), "Factors of Employees' Effective Voice in Corporate Goverance", Journal of Management \& Governance, 9(3-4), 287-313.

ÇAKICI, A. (2007), "Örgütlerde Sessizlik: Sessizliğin Teorik Temelleri ve Dinamikleri”, Çanakkale Üniversitesi Sosyal Bilimler Enstitüsü Dergisi, 16(1), 145-162.

ÇAKICI, A. (2010), Örgütlerde İşgören Sessizliği Neden Sessiz Kalmayı Tercih Ediyoruz?, Detay Yayıncılık, Ankara.

DANIŞMAN, A., ÖZGEN, H. (2003), “Örgüt Kültürü Çalışmalarında Yöntem Tartışması: Niteliksel-Niceliksel Yöntem İkileminde Niceliksel Ölçümler ve Bir Ölçek Önerisi”, Yönetim Araştırmaları Dergisi, 3(2), 91-124.

DETERT, J. R., EDMONDSON, A. C. (2006), "Everyday Failures in Organizational Learning: Explaining the High Threshold for Speaking Up at Work", Harvard Business School Working Paper Series, 6-24.

FARRELL, D. (1983), "Exit, Voice, Loyalty, and Neglect as Responses to Job Dissatisfaction: A Multidimensional Scaling Study", Academy of Management Journal, 26(4), 596-607. 
GAO, L., JANSSEN, O., SHI, K. (2011), "Leader Trust and Employee Voice: The Moderating Role of Empowering Leader Behaviors", The Leadership Quarterly, 22(4), 787-798.

HIRSCHMAN, A. (1970), Exit, Voice, and Loyalty: Reponses to Decline in Firms, Organisations, and States, Harvard University Press, Cambridge.

HOFSTEDE, G. (1991), Cultures and Organisations-Software of The Mind: Intercultural Cooperation and Its Importance for Survival, Mcgraw-Hill.

KISH-GEPHART, J. J., DETERT, J. R., TREVIÑO, L. K., EDMONDSON, A. C. (2009), "Silenced by Fear: The Nature, Sources, And Consequences of Fear at Work", Research in Organizational Behavior, 29(2009), 163-193.

KNOLL, M., DICK, R. (2013), "Do I Hear the Whistle...? A First Attempt to Measure Four Forms of Employee Silence and Their Correlates", Journal of Business Ethics, 113(2), 349-362.

LECK, J. D., SAUNDERS, D. M. (1992), "Hirschman's Loyalty: Attitude or Behavior?", Employee Responsibilities and Rights Journal, 5(3), 219-230.

MILLIKEN, F. J., MORRISON, E. W. (2003), "Shades of Silence: Emerging Themes and Future Directions for Research on Silence in Organizations", Journal of Management Studies, 40(6), 1563-1568.

MILLIKEN, F. J., MORRISON, E. W., HEWLIN, P. F. (2003), “An Exploratory Study of Employee Silence: Issues that Employees don't Communicate Upward and Why", Journal of Management Studies, 40(6), 1453-1476.

MORRISON, E. W. (2011), "Employee Voice Behavior: Integration and Directions for Future Research", The Academy of Management Review, 5(1), 373412.

MORRISON, E. W., MILLIKEN, E J. (2000), "Organizational Silence: A Barrier to Change and Development in a Pluralistic World", Academy of Management Review, 25(4), 706-725.

MORRISON, E. W., MILLIKEN, F. J. (2003), "Speaking Up, Remaining Silent: The Dynamics of Voice and Silence in Organizations", Journal of Management Studies, 40(6), 1353-1358.

NADER, L. (2001), "Breaking the Silence-Politics and Professional Autonomy", Anthropological Quarterly, 75(1), 161-168. 


\section{Z. UÇAR}

NIKOLAOU, I., VAKOLA, M., BOURANTAS, D. (2008), "Who Speaks up At Work? Dispositional İnfluences on Employees' Voice Behavior", Personnel Review, 37(6), 666-679.

ÖZDEMİR, L., UĞUR, S. S. (2013), "Çalışanların 'Örgütsel Ses ve Sessizlik' Algılamalarının Demografik Nitelikler Açısından Değerlendirilmesi: Kamu ve Özel Sektörde Bir Araştırma", İktisadi ve İdari Bilimler Dergisi/Journal of Economics and Administrative Sciences, 27(1), 257-281.

PIDERIT, S. K., ASHFORD, S. J. (2003), "Breaking Silence: Tactical Choices Women Managers Make in Speaking Up About Gender-Equity Issues", Journal of Management Studies, 40(6), 1477-1502.

PINDER, C. C., HARLOS, K. P. (2001), "Employee Silence: Quiescence and Acquiescence as Responses to Perceived İnjustice", Research in Personnel and Human Resources Management, 20, 331-370.

PREMEAUX, S. F., BEDEIAN, A. G. (2003), "Breaking The Silence: The Moderating Effects of Self-Monitoring in Predicting Speaking up in The Workplace", Journal of Management Studies, 40(6), 1537-1562.

QUINN, R., SPREITZER, G. (1997), "The Road to Empowerment: Seven Questions Every Leader Should Answer”, Organizational Dynamics, 26(2), 37-50.

SHOJAIE, S., MATIN, H. Z., BARANI, G. (2011), "Analyzing The Infrastructures of Organizational Silence and Ways to Get Rid of It", Procedia-Social and Behavioral Sciences, 30, 1731-1735.

ŞEHITOĞLU, Y. (2010), Örgütsel Sessizlik Örgütsel Vatandaşlık Davranışı ve Algılanan Çalışma Performansı İlişkisi, Gebze İleri teknoloji Enstitüsü, Yayımlanmamış Doktora Tezi, Kocaeli.

TANGIRALA, S., RAMANUJAM, R. (2008), "Exploring Nonlinearity in Employee Voice: The Effects of Personal Control and Organizational Identification", Academy of Management Journal, 51(6), 1189-1203.

ÜÇOK, D. I., TORUN, A. A. (2015), “Örgütsel Sessizliğin Nedenleri Üzerine Nitel Bir Araştırma”, İ̧ ve İnsan Dergisi, 2(1), 27-37.

VAKOLA, M., BOURADAS, D. (2005), "Antecedents and Consequences of Organizational Silence: An Empirical Investigation”, Employee Relations, 27(5), 441-458.

YILDIRIM, A., ŞİMŞEK, H. (2012), Sosyal Bilimlerde Nitel Arastirma Yöntemleri (Sekizinci Baskı). Seçkin Yayıncılık, Ankara. 